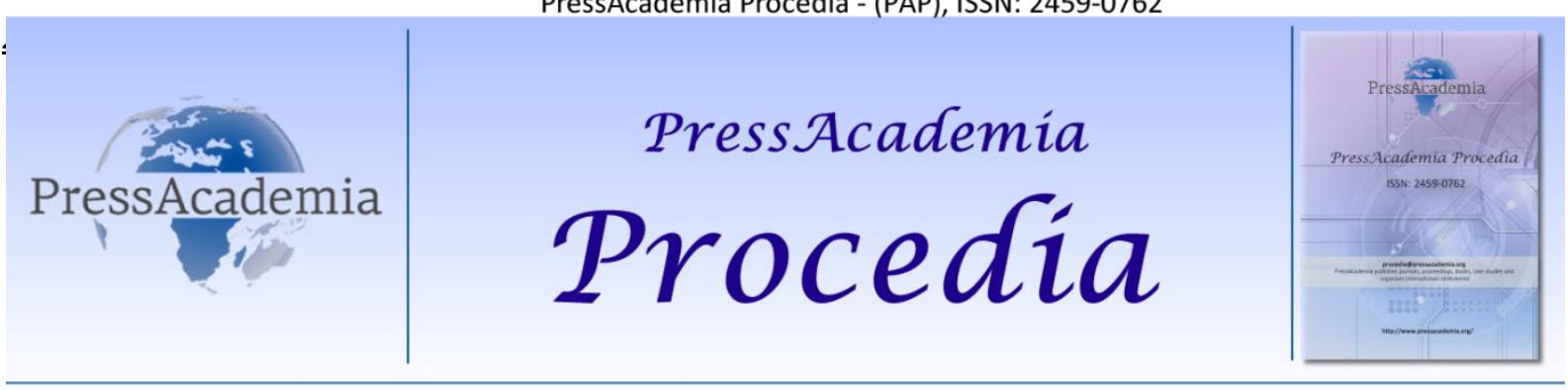

2nd World Conference on Technology, Innovation and Entrepreneurship

May 12-14, 2017, Istanbul, Turkey. Edited by Sefer Şener

\title{
TECHNOLOGICAL BRANCH INVESTMENTS IN PHYSICAL BRANCHING STRATEGIES OF SMALL AND MEDIUM SCALE BANKS
}

\author{
DOI: 10.17261/Pressacademia.2017.535 \\ PAP-WCTIE-V.4-2017(27)-p.199-212
}

\section{Selman Ortakoy}

Kuveytturk Participation Bank, selman.ortakoy@kuveytturk.com.tr

\begin{abstract}
Despite the increasing trend in online channels, small and medium-sized banks, whose physical coverage is still low in Turkey, are still required to invest in physical channels. In that sense, investments in technological branches could be an alternative for banks. The technological branches, hybrid channels between the physical branch and the internet/ mobile channels, are also presented as a different channel model in order to increase the penetration of the bank's new geographical locations. In this regard, XTM Branches of a medium scale Bank has been taken as a technological branch example. The bank's XTM Branch investment and the physical branch option have been compared to a cost-based approach. It has been questioned how many additional potential locations in Turkey could be chosen in accordance with this Bank's Branch Location Decision Parameters if the Bank decides to invest in XTM Branches rather than classic physical branches.
\end{abstract}

Keywords: Technological branch, XTM branch, banking, branching strategies JEL Codes: K10

\section{INTRODUCTION}

Owing to the profit margins that have narrowed down recently in the banking sector of Turkey, the capital and asset return ratio have been declining. This financial situation necessitates much more cost and efficiency oriented approaches in the Bank's strategies. Physical branch channels generate great increases in personnel, rent and other running cost items. When channel strategies are evaluated from a cost-oriented point of view, it is the goal of all Banks to provide their customers' channel migration with internet / mobile channels, which have a very low marginal transaction cost comparing to the physical branch channel. This phenomenon has derived the banks to improve their investment in internet and mobile channels recently and to develop marketing strategies to provide channel migration.

Allegedly, the ability to access many banking services of mobile devices and computers without having to go to physical branches has increased similarly to the spread of mobile devices in recent years. Whereas the number of active internet banking customers in Turkey has increased from 8.6 million to 20.4 million in the last 5 years (2011-2016); the number of active customers in mobile banking rose to 19.2 million from 445 in the same period (Turkish Bankers Association, Internet and Mobile Banking Statistics, December 2016).

While the customers' willingness and interest in online channel affects the efficiency of internet and mobile channel investments, there is another problem on small and medium sized banks, exclusively those with the low physical market coverage, to be dealt with. Banks usually acquire new customers with physical branches and, then migrate some transactions of these customers to online channels. The difficulty of making it possible for the customers to open accounts directly via online channels in a micro-market does not enable these Banks to incease their market share. Through this problem, it is investigated to what extent physical branch channels could be abandoned and the investment in hybrid solution proposals like technological physical branches could be an alternative. 


\section{PHYSICAL BRANCH REQUIREMENT in BANKING SECTOR}

How the physical branch strategies will be formed while banks moving some transactions of their customers from physical channels to online platform is an important question. The factors listed below indicate that physical contact points will decline in number but will not disappear completely.

\subsection{Customer's Low Online Channel Acceptance Level}

One of the most important factors influencing the ability of technological developments to change our daily life is the willingness of customers to use that kind of technology. No matter how big a technological innovation companies bring out, the sustainability of these investments go hand in hand with the right marketing strategy alongside the integration and implementation of this innovation in business models. Companies have to estimate and assess how ready their business areas and customers are capable to adapt to the innovation offered to them, as well as whether they posses the human resource capacity, knowledge / accumulation, innovation ecosystem and adequate capital.

Among the studies on adaptation to technology, the most widely accepted study is the Technology Acceptance Model (TAM) developed by Davis (1986) (Thakur and Srivastava, 2014). The perceived usefulness and ease of use influence the intentions of customers to use the technology and that affects their behavior of use. An advanced version of this thesis (TAM2) was studied by Venkatesh and Davis (2000). Furthermore, three social factors (subjective norm, volunteriness and image) and three perceptual processes (job relevance, output quality and result demonstrability) which affect the behavior of customers in terms of technology use are also pointed out. The Technology Acceptance and Use Theory developed by Venkatesh et al. (2003) also analyzes the factors affecting the intentions of the customers to use the technology. Expected convenience, expected benefits, social pressure, and facilitating factors affect the customers' adaptation to technology. The study by Thakur and Srivastava (2014) demonstrates that customer safety concerns had a negative effect on mobile transactions. On the other hand, this study acknowledges that mobile service providers should primarily expand their innovative customer segments.

The studies conducted by Eastlick (1996), Gatignon and Robertson (1991), Ellen, Bearden and Sharma (1991), Meuter and Bitner (1997), Parasuraman (2000), Raub (1981), Ray and Minch (1990), Dabholkar (1996), Langeard et al. (1981) and Breakwell et al. (1986), Gist (1987), Igbaria and Parasuraman (1989) highlight that the level of complexity of the process, the perception of risk, the need to interact with other people, the fear of technology, the level of education and low income have negative affect on the ability of clients to make transactions by themselves (Meuter et al., 2005). The study by Baker et al. (2007) states that cultural and even spritual prejudices against imported technological applications and not driven by internal factors are prevalent in particularly low education level communities in developing eastern countries. In the study conducted by Rotchanakitumnuai and Speece (2003) in a far Eastern country, concerns about security and legal problems of especially corporate customers are identified as the most important obstacles for their usage of online channels. A research by Gerrard et al. (2006) in Far East also demonstrates that the perceived risk for online transactions, the lack of information, and the need to interact with people are the obstacles to online banking operations. A study by Lee and Jaramillo (2013) in three emerging countries indicates that customers' fear and insecurity feelings has negative effect on their approach to branchless banking and that the benefits of online banking are not clearly understood in all segments. The research by Paul and Lim (2015) compares customers' internet banking adaptation levels in Malaysia and the United States and encountered that customers in US have more positive attitude towards internet banking on account of cultural factors.

The study on the difficulties in promoting online banking transactions in Turkey by Okumuş (2010) points out that the lack of information and the fear of technology are important factors affecting customers negatively. It is more difficult to convince especially female customers and customers with low level of education in online banking services, and these customers opt for physical banking branches instead of these channels. The studies conducted by Pala and Kartal (2010), Usta (2005), Akın and Karaboğa (2011), Durer et al. (2009), Cebeci (2015), Özdemir and Hoecht (2008), Ustasüleyman and Eyüboğlu (2010), and Kaya and Arslan (2016) indicate that the greatest obstacle for bank customers' online migration is security and that banks should advance their online transaction security to succeed in digitalization of transactions. The research by Yildiz and Karadirek (2014) suggests that banks should place emphasis on security in order to increase the number of internet channel customers and provide extra assurance to customers that this channel could perform transactions in a complete and correct way. Oktay and Orçanlı (2014) conducted a study between academicians and found that even in this segment, transaction insecurity and difficulty of transactions are the reason for not using online branches. In the study conducted by Khalilov and Gundebahar (2012), it is asked why they are in need of a branch instead of using ATMs, which are a self-service service model. In all age groups, the answers in the foreground are "to make transactions that ATM does not do", "looking for human interaction, and confidence in the process" and "to obtain detailed information of transactions from bank personnel". Unlike the younger group, the older ones' response (to avoid incorrect operations) reveals the importance of insecurity of this customer segment in technological devices. 


\subsection{Inadequacy of Online Channels in Account Opening and Credit Transactions}

The basic function of the banks is to mediate between the sector with more funds and the sector in need of funds. In this respect, even when the effect of all other factors is minimized, it is observed that the physical contact points of the banks are crucial in establishing both the trust of the banks to credit customers and the trust of the deposit owners to the banks. The ease of operation and the cost advantage of online channels lead customers to this channel, but physical channels continue to play a key role in assuring trust between customers and banks. In this sense, it is the optimum channel approach for banks that online services are not completely independent but serve together with physical channels. In opening online accounts, in the process of understanding and using the internet and mobile channel features and in resolving emerging problems, customers continue to receive support from branch personnel. (Yap et al., 2009)

Banks face problems in obtaining the required documents and wet signatures of the customers in accordance with the risk management and related regulations, especially during the application process of credit transactions on the internet. It is especially important that the quality and reliability of the data to be provided from the customers in the credit processes are high. However, in developing countries like Turkey, the quality of the customers' data especially in the small business segment, pose a greater credit risk in the credit transactions to be made via online channels. (Chavan, 2013) These problems lead to the fact that credit applications made from mobile/internet channels result in a low limit allocation compared to the credit applications conducted in physical branches. In order to overcome these problems, the banks take the transactions having started in online branches to the physical ones so as to correctly identify the credentials of the customers and to get the credit guarantees correctly and to end the transaction in the physical branch with an omnichannel approach. (Mermod, 2015)

Another difficulty encountered by banks is that they can not open new accounts through the internet and mobile channels. Therefore, marketing activities in physical branches result in new customer acquisitions and account openings, and then customers are transferred to technological channels through channel migration. In addition, the lack of physical contact with the customers in any environment before and after the opening the accounts in online channels leads to number of problems in the customer management process of banks. Online channels without the support of physical branches may not be enough for banks to understand the customers better, to build the customer related data, to determine correct segment, product and channel strategy, to design the necessary marketing activities, and to solve some problems faced by customers in physical market. (Koskosas, 2011) The fact that the banks establish relationships with particularly efficient customer groups through the internet environment significantly reduces customer loyalty. Customers who do not have a personal dialogue with the bank can immediately change the bank with a better offer they can find in the market. (Angelakopoulos and Mihiotis, 2011)

\subsection{Physical Market Penetration of Small / Medium Scale Banks}

Since the focus of this study is particularly the small and medium-sized banks, conventional banks in Turkey are grouped in accordance with their asset sizes as follows, but Participation Banks are not included in this categorization because of their different business model. Furthermore, the physical market penetrations of each group are examined separately.

Table 1: Grouping of Banks in Turkey*

\begin{tabular}{llll}
\hline First Scale Banks & Second Scale Banks & Third Scale Banks & Participation Banks \\
\hline Ziraat Bank & Deniz Bank & Alternatif Bank & Kuveyt Türk Participation Bank \\
İş Bank & Finans Bank & Anadolu Bank & Türkiye Finans Participation Bank \\
Garanti Bank & Türkiye Ekonomi Bank & Fiba Bank & Albaraka Türk Participation Bank \\
Akbank & ING & Burgan Bank & Asya Participation Bank \\
Yapı Kredi Bank & HSBC & Şeker Bank & Ziraat Participation Bank \\
Halk Bank & Odea Bank & Tekstil Bank & Vakıf Participation Bank \\
Vakıflar Bank & & Turkland Bank & \\
& & & \\
\hline
\end{tabular}

\footnotetext{
* Banks' audited financial data for June 2016 were used. (Turkish Bankers Association, June 2016)
}

There is at least one physical bank branch providing financial services in 955 of total 970 counties located in Turkey. Although this figure demonstrates that banks have a large geographical penetration rate; Ziraat Bank, the biggest public bank in Turkey, is very effective in increasing this ratio. Ziraat Bank also acts as the central bank in the countryside, fulfills all banking transactions such as payments\&transfers for public institutions and organizations. Therefore, banks on the first scale were examined separately with and without Ziraat Bank. 
Table 2: Branch Distributions of Banks in Different Types of Counties* in Turkey

\begin{tabular}{|c|c|c|c|c|c|}
\hline & & $\begin{array}{c}\text { County of } \\
\text { Metropolitan }\end{array}$ & $\begin{array}{l}\text { Countyside } \\
\text { County }\end{array}$ & Central County & Total \\
\hline & Total County Number & 519 & 400 & 51 & 970 \\
\hline \multirow{5}{*}{ 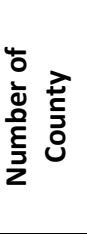 } & First Scale Banks & 513 & 391 & 51 & 955 \\
\hline & First Scale Banks (Except Ziraat Bank) & 353 & 157 & 51 & 561 \\
\hline & Second Scale Banks & 270 & 68 & 49 & 387 \\
\hline & Third Scale Banks & 165 & 29 & 40 & 234 \\
\hline & Participation Banks & 149 & 6 & 40 & 195 \\
\hline \multirow{7}{*}{ 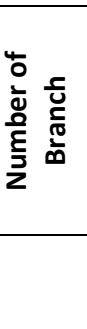 } & First Scale Banks & 6344 & 887 & 607 & 7838 \\
\hline & First Scale Banks (Except Ziraat Bank) & 5101 & 477 & 475 & 6053 \\
\hline & Second Scale Banks & 1993 & 107 & 204 & 2304 \\
\hline & Third Scale Banks & 607 & 31 & 42 & 680 \\
\hline & Participation Banks & 800 & 8 & 111 & 919 \\
\hline & Total Branch Number & 9744 & 1033 & 964 & 11741 \\
\hline & Percentage in Total Branch Number & $83 \%$ & $9 \%$ & $8 \%$ & \\
\hline
\end{tabular}

*County of Metropolitan: Includes central and the other counties of metropolitan cities in Turkey.

Countyside County: Includes noncentral counties of non-metropolitan cities in Turkey.

Central County: Includes only central counties of non-metropolitan cities in Turkey.

Examining the distributions of the banks, it is observed that $83 \%$ of the bank branches in Turkey concentrate on the counties of the metropolitan cities. These counties (519 county in total) constitute $54 \%$ of the total number of counties in Turkey. Banking physical branch penetration in the central counties of non-metropolitan cities is also soaring. While $5 \%$ of the total number of counties constitute such counties (51 county in total), $8 \%$ of the total number of branches is prevalent in these counties. On the other hand, although 400 countryside counties constitute $41 \%$ of the total number of counties in Turkey, only $8 \%$ of the bank branches is available in these counties. 391 of these counties have at least one bank branch. However, except for Ziraat Bank, only 157 (39\%) of these counties can reach banking services.

$87 \%$ of the total branches of the second-scale banks, $89 \%$ of the third-scale banks and $87 \%$ of the Participating Banks are located in the counties of metropolitan cities. On the other hand, of the 400 countryside counties of the other cities, 68 have second-scale bank branches, 29 have third-scale bank branches and only 6 have branches of participation banks.

Countryside counties has a share of $12.3 \%$ of the total population, $11.6 \%$ of the potential banking population, $8.7 \%$ of the total micro enterprises, $8.4 \%$ of workplaces which has more than ten employees and $5 \%$ of the total volume of deposits and loans. It is pointed out that the physical penetration of the second and third-scale banks in these counties is quite low. $4.5 \%$ of the total branches of the second and third scale banks and only $1 \%$ of the branches of the participation banks are permanent in these counties. In that sense, increasing the physical penetration in these regions for participation banks is more significant. It is also unlikely for these banks with no physical contact with the customer to attract new customers through online channels in such locations where customers has lower technology usage rates.

\section{DECREASING PROFITABILITY IN BANKING SECTOR AND COST-DRIVEN CHANNEL STRATEGY}

In Turkey, profit margins of the banking sector have narrowed and profitability ratios have declined in the last decade. This has made the banks pay more attention to cost optimization in order to sustain their profitability.

Figure 1: Banking Sector Profitability Ratios in Turkey 


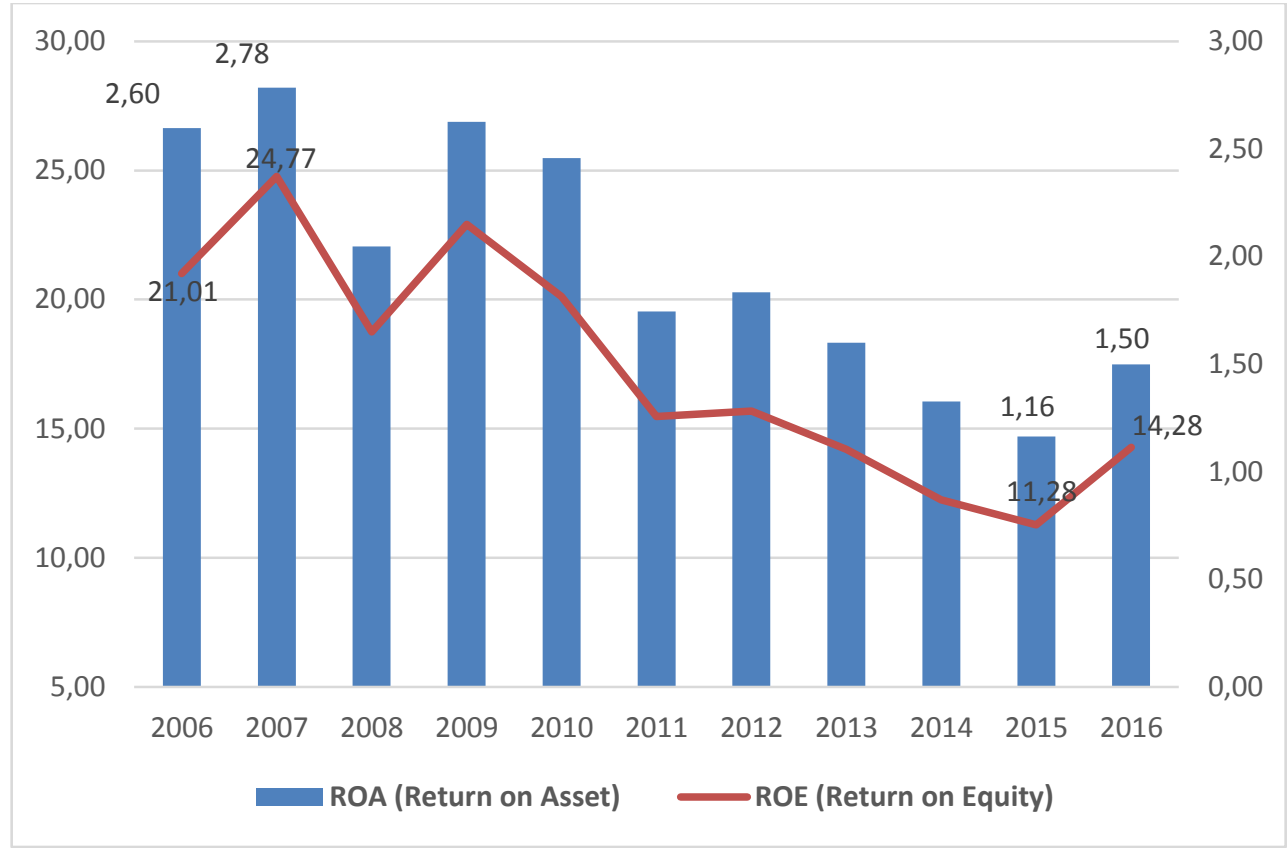

Banking Regulation and Supervision Agency, December 2016, "Turkish Banking Sector Interactive Monthly Bulletin".

The return on the equity of banking sector was $21 \%$ in 2006 and $24.8 \%$ in 2007 , falling down to $11 \%$ in 2015 . The return on assets decreased from $2.6 \%$ to $1.16 \%$ in the same period. Declining number of branches and staffs in the sector in 2016 highlights the cost-oriented approach of the banks and the effect of this approach on branching strategies. After the decline in 2016, the number of branches and staffs declined to the levels reached before 2013. This decline has led to an upward improvement in profitability ratios in 2016.

Figure 2: Branch and Staff Numbers in Banking Sector in Turkey

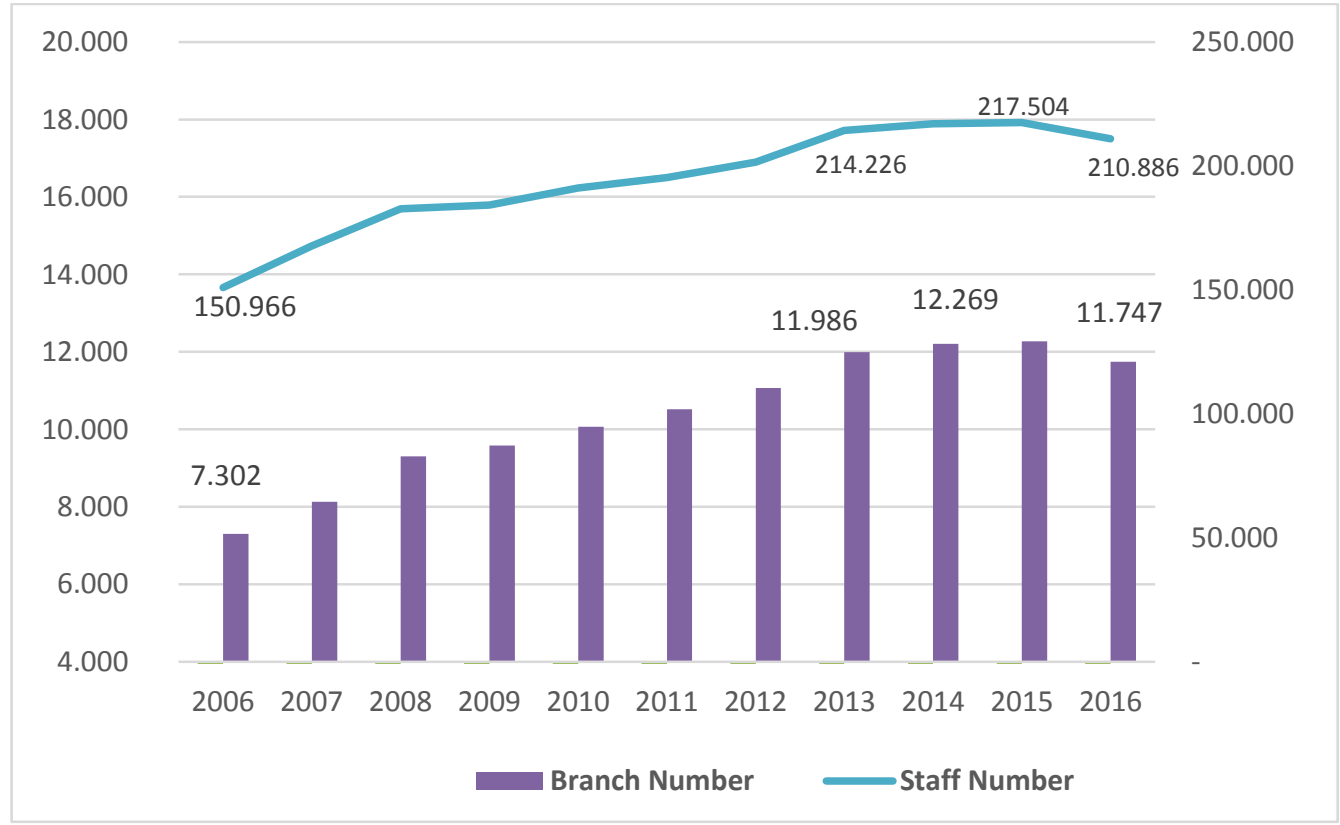

Banking Regulation and Supervision Agency, December 2016, "Turkish Banking Sector Interactive Monthly Bulletin".

Decreasing profitability in the sector and cost-oriented strategies obstruct the banks to open physical branches in countryside locations, especially those with low financial potential. This is an obstacle especially for the small and mediumsized banks and Participation Banks which have not yet entered in these micro markets physically. 
For the sake of the reasons mentioned above, banks' physical presence in the market are variated into "unmanned branch", "technological branch", "self-service branch" and so on instead of classic bank branches. These branches are equipped with fewer staff (or no staff) and more technological channels compared to traditional physical branches and they have a business model which enables customers to perform banking transactions on the internet, mobile, ATM and newly developed set of devices. These models reveal a hybrid physical banking model and have a feature which provides the physical touch of the bank with the customers but allows the transfer of transactions to the technology concurrently.

\section{A TECHNOLOGICAL BRANCH EXAMPLE: XTM}

XTM Branches have a hybrid business model between classical physical bank branches and ATMs where all transactions of the customers conducted by themselves. XTM Branches are kind of physical bank branches which enable banks to increase their physical market penetration. XTM devices, in feature, are similar to a highly developed ATM. The most important reason why this device is considered in a branch concept is that it combines the ATM concept and the classic branch concept to create the ideal structure. ATMs can only do a small part of the transactions to be performed in physical bank locations. Classic branches have a structure which is far from technology and cost optimization. On the contrary, XTM Branches have much more sophisticated devices than a simple transaction set of ATMs and they also have much cheaper physical branch concept. (Khalilov and Gündebahar, 2012)

\section{Picture 1: XTM Appearance (Kuveyt Turk Participation Bank)}
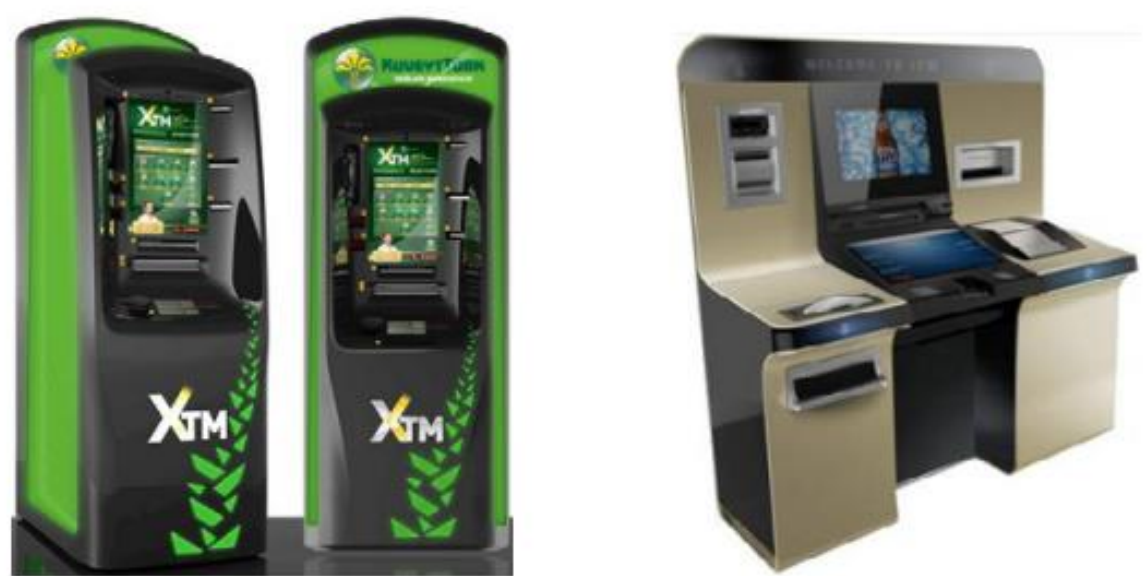

XTM Branches can be deployed as unmanned branches with a self-service business model, as well as mini-branches along with sales staff to facilitate the customers' getting used to use technology. The most important cost advantage of XTM branches is the lack of need for staff such as teller, back office and security officer. Teller operations are performed by the customer totally through the device. Since there is no need for tellers and ATM-like operations are performed through XTM devices, there is no need for security officers too.

XTM Branches have the following transaction features:

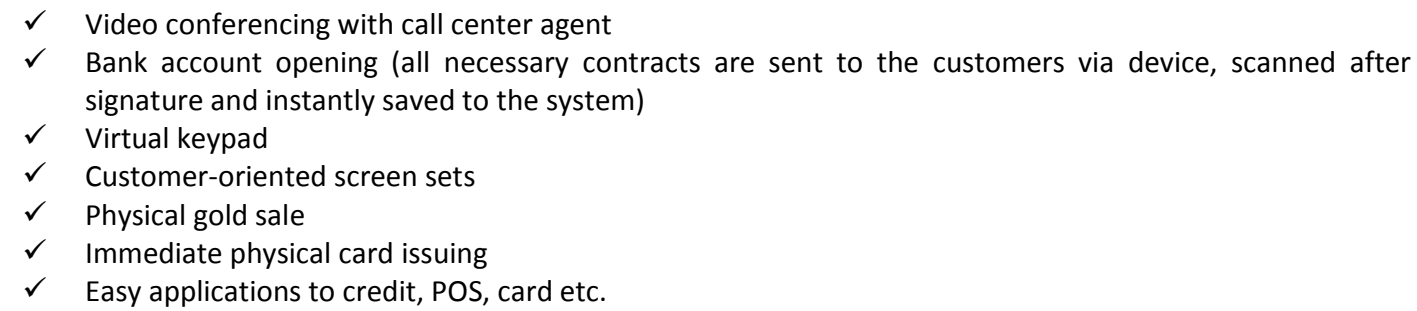

XTM Branches meet the physical channel needs of the Banks with less cost and enable them:

$\checkmark \quad$ to increase their physical market penetration,

$\checkmark$ to make it easier for technology-fearing customers to connect with technology by providing face-to-face communication with them, 
$\checkmark \quad$ to carry out transactions such as account opening and credit utilization which can not be done via online channels and ATMs, at a lower unit cost than the traditional branches,

$\checkmark \quad$ to obtain the signatures of customers not through the tellers or sales staff but through the technological devices in case of transactions requiring wet signature.

It is possible for XTM branches, as a hybrid channel, to be an alternative for banks in their entrance into the micro-markets only if they are less costly than traditional bank branches.

\section{COST-FOCUSED COMPARISON OF XTM BRANCHES AND PHYSICAL BRANCHES}

The table below compares the average investment and operating costs of classical branches and XTM branches using the data of Kuveyt Turk Participation Bank. Due to the confidentiality of the bank data, real figures were not used and comparative cost information was offered in this comparison.

Table 3: The Comparison between Costs of the Branch Types

\begin{tabular}{clcc} 
& & XTM Branch & $\begin{array}{c}\text { Classic Physical } \\
\text { Branch }\end{array}$ \\
\hline Capital Expenditure & Investment Cost & 0.55 & 1 \\
\hline & & & \\
\hline \multirow{3}{*}{ Operational Expenditure } & Staff & 0.35 & 1 \\
& Rent & 0.35 & 1 \\
& Depreciation & 0.67 & 1 \\
& Running (Energy etc.) & 0.51 & 1 \\
& Other & 0.69 & 1 \\
\hline & TOTAL & $\mathbf{0 . 4 5}$ & $\mathbf{1}$
\end{tabular}

This cost structure demonstrates that XTM branches are 2.2 times cost-effective than classical bank branches. This has also resulted in the XTM branches having the same advantage over the size of the balance sheet required to reach breakeven point.

\section{PHYSICAL LOCATIONS SELECTION MODEL via EXAMPLE OF THE BANK}

The main argument of this study is to determine how small and medium sized banks will locate technological branches in their channel strategy and location selection models. It is unlikely that XTM branches will perform financially as well as classical bank branches owing to the low number of staff, the low probability of customers' propensity for technology, and the potential loss of trust in customers due to lack of teller staff. In this respect, the performance of the XTM branches will be as important as their cost advantage.

In this part of the study, additional physical locations to be opened in Turkey were analyzed based on the parameters used in Kuveyt Turk Participation Bank (hereinafter referred to as the Bank). XTM Branches are even less costly, so they can be effective even at locations which do not have enough potential to open a classical branch. On the other hand, it will not be possible to expect the performance of a classical physical branch from an XTM Branch due to the reasons mentioned above. In this case, it is misguided to determine the potential of the location only in terms of cost so that the XTM branch could be successful. Instead, it is tried to determine the required minimum financial potential in a location for an XTM Branch establishment by taking advantage of the location features of the existing XTM branches.

The following steps have been followed as a method of determining the potential locations for the classic branches and the XTM branches:

$\checkmark \quad$ The parameters and scoring methodology used by the bank in selecting branch locations were examined.

$\checkmark$ Based on this methodology, the financial potential score of all the counties in Turkey was calculated.

$\checkmark \quad$ The geographical location distributions of the classical physical branches and XTM branches of the bank were investigated and the channel strategy was analyzed on a score basis.

$\checkmark$ Scorecards of existing branches, negotiations made by bank managers and Bank's channel strategy were examined and the criterias for newly opened branch locations were clarified.

$\checkmark \quad$ It was calculated how many potential locations are available for these two channels among the counties where the bank has not opened physical locations so far

$\checkmark$ Through this method, it has been analyzed that in how many additional places where the physical branch can not be opened because of insufficient potential, the bank can increase its physical presence by using XTM branches. 


\subsection{Location Selection Parameters}

There are many studies about the problem of location selection of banks. In many of such studies, it is possible to recognize that there are supporting results. The appropriateness of the approach of the bank's existing location model has been evaluated in accordance with the literature.

In the study conducted by Willer (1990); the working population, income distribution and individual / business potential are effective in determining the branch locations of banks. In the research by Cinar (2009) and Cebi and Zeren (2008), the demographic (urban, population growth rate), socio economic (gross national product per capita, literacy rate, rate of population with higher education, average household size, employee rate, employer rate), sectoral employment (agricultural employment rate, manufacturing employment rate, construction employment rate, services employment rate), banking (number of bank, number of branch, bank deposit per branch, credit per branch, bank deposit per capita, credit per capita) and trade potential (number of firms, number of organized industrial zone) data types are used to determine the correct branch location for banks. The study acknowledges that banking, demographic, trade potential, and socio-economic data types stand out in terms of importance, while sectoral employment data are less important. In the study conducted by Cinar (2011); population, gross domestic product, the existence of rival banks, customer potential and commercial activity were used as the leading data for bank branches' location selection. In the research by Weon et al. (2010), the level of income, the level of spending, the quantity of businesses, and the number of workers were determined as effective data for bank location selection. In the work of Stove (2014), the three most important factors in the banks' location selection are determined as the other bank branches, population and the tax paid by the districts. Other studies compiled by Basar et al. (2015) shows that while Doyle et al. (1981) uses population, the status of rival bank branches, worker and employer ratio, demographic characteristics, ease of access and number of firms; Boufounou (1995) uses population, rival bank branches, average household income, population growth rate and number of firms; Zhao et al. (2004) uses population, rival bank branches, labor and employer ratio, transportation convenience and income level as the most important data in their location selection model. Basar et al. (2015) uses transaction volume in their own studies as the main criteria for the opening of bank branches. It is pointed out that the number of potential customers in the individual segment and commercial company potential in the commercial segment are the secondary important data.

In the selection of the bank's location, it was firstly analyzed as the statistical data which mostly affects the performance of the existing branches. Then, the existing literature and interviews with the bank managers and analyzes were interpreted together. Eventually, the retail and commercial scores of the locations were calculated separately and the retail and commercial scores were weighted in accordance with the strategic financial expectations of the Bank from newly opened branches. As a result of this method, the potential banking scores of all the counties in Turkey were obtained. In the province of Istanbul, the details of the neighborhoods were included in the analysis and scored separately in line with their financial potentials.

Table 5: Parameters and Weights Used to Calculate Location Potential Score

\begin{tabular}{rcc}
\hline Parameters & Commercial Score & Retail Score \\
\hline Houselhold Income & $0 \%$ & $15 \%$ \\
Potencial Customer Number & $0 \%$ & $35 \%$ \\
The Number of C+ Segment Customer & $0 \%$ & $8 \%$ \\
Number of Large-Scale Company (250+ staff) & $45 \%$ & $0 \%$ \\
Number of Micro-Scale Company (0-10 staff) & $3 \%$ & $0 \%$ \\
Number of Small-Scale Company (10-49 staff) & $5 \%$ & $0 \%$ \\
Number of Large-Scale Company (50-259 staff) & $20 \%$ & $0 \%$ \\
Total Participation Bank Branch Number & $27 \%$ & $32 \%$ \\
Foot Traffic & $0 \%$ & $10 \%$ \\
\hline
\end{tabular}

While the potential banking scores of the neighborhoods in Istanbul were calculated, the "shopping volume" data was used instead of "household income".

\subsection{Potential Scores of Turkeys' Counties and Istanbul's Neighborhoods}


There are totally 970 counties in Turkey. While 519 of these are constituted by the counties of the metropolitan cities, the non-metropolitan provinces have 51 central counties and 400 countryside counties. Based on the methodology followed, the potential banking score of 970 banks in Turkey was calculated. In terms of analysis, banking scores in accordance with the county types are important.

Table 6: Potential Banking Scores of Counties by Type in Turkey

\begin{tabular}{rcccc}
\hline Score Range & $\begin{array}{c}\text { County of } \\
\text { Metropolitan }\end{array}$ & $\begin{array}{c}\text { Countryside } \\
\text { County }\end{array}$ & Central County & Total \\
\hline $80-100$ & 26 & & & 26 \\
$60-80$ & 30 & & 18 & 32 \\
$40-60$ & 48 & 9 & 19 & 66 \\
$20-40$ & 110 & 391 & 12 & 138 \\
$0-20$ & 305 & $\mathbf{4 0 0}$ & $\mathbf{5 1}$ & $\mathbf{5 1}$ \\
Total & $\mathbf{5 1 9}$ & $\mathbf{9 7 0}$ \\
\hline
\end{tabular}

According to Table 6, the total 26 counties with the highest score group in Turkey and $94 \%$ of the counties in the second highest score group are the metropolitan counties. On the other hand, $98 \%$ of the 400 counties of non-metropolitan cities seem to have the lowest banking score. $73 \%$ of the central counties of non-metropolitan cities are in the third and fourth range banking score group.

It is observed that $78 \%$ of the neighborhoods belong to the two lowest score group in the neighborhood scoring obtained in Istanbul province. When at least one bank branch is located in all the two highest score groups, only $18 \%$ of the neighborhoods in the lowest scorer group and $66 \%$ in the second lowest scorer area have bank branches. This table shows that banking sector has a branch distribution in parallel with the potancial score calculated in this model in Istanbul province.

Table 7: Potential Banking Score Distribution of the Neighborhoods in Istanbul

\begin{tabular}{rcc}
\hline Score Range & $\begin{array}{c}\text { Neighborhood } \\
\text { Number }\end{array}$ & $\begin{array}{c}\text { Neighborhoods with Any } \\
\text { Bank Branches }\end{array}$ \\
\hline $80-100$ & 40 & 40 \\
$60-80$ & 52 & 52 \\
$40-60$ & 121 & 106 \\
$20-40$ & 363 & 238 \\
$0-20$ & 375 & 68 \\
Total & $\mathbf{9 5 1}$ & $\mathbf{5 0 4}$ \\
\hline
\end{tabular}

\subsection{Location Penetration and Potential Scores of The Bank's Current Branches}

At the time of the work, the Bank (Kuveyt Türk Participation Bank) used to operate in 379 branches in 68 different cities and 174 different counties. There are 13 cities in Turkey where the bank has not opened any branches yet.

Table 8: Distribution of the Bank Branches by County Types

\begin{tabular}{lcccc}
\hline \multicolumn{1}{c}{ County Type } & $\begin{array}{c}\text { Total County } \\
\text { Number }\end{array}$ & $\begin{array}{c}\text { The Number of } \\
\text { Counties where the } \\
\text { Bank is located }\end{array}$ & $\begin{array}{c}\text { Number of } \\
\text { The Bank's } \\
\text { Total Branches }\end{array}$ & $\begin{array}{c}\text { Number of Counties } \\
\text { where Other Banks' } \\
\text { Branches are located }\end{array}$ \\
\hline County of Metropolitan & 519 & 136 & 335 & 514 \\
Clountryside County & 400 & 1 & 1 & 391 \\
Central County & 51 & 37 & 43 & 51 \\
Total & $\mathbf{9 7 0}$ & $\mathbf{1 7 4}$ & $\mathbf{3 7 9}$ & $\mathbf{9 5 6}$ \\
\hline
\end{tabular}

As a medium-sized bank, the Bank operates in only $18 \%$ of the total counties and $78 \%$ (136 counties) of these are the counties of metropolitan cities. There are branches in the 37 central counties of the 51 non-metropolitan cities, but not in 14 of them. Moreover, among 400 countryside counties of non-metropolitan cities, the bank operate at only one location. The Bank has concentrated its physical branch investments in metropolitan cities and central counties of other cities 
mostly. While at least one bank branch is found in $99 \%$ of the counties in Turkey, there are 796 counties (82\%) in which the bank does not open branch offices.

The bank has 158 branches in the province of Istanbul. While at least one of the other Banks is located in the 504 neighborhoods in Istanbul, the Bank operates in only 142 neighborhoods.

Table 9: Branches of the Bank Operating in Istanbul

\begin{tabular}{ccc}
\hline $\begin{array}{c}\text { Total Neighborhood } \\
\text { Number in Istanbul }\end{array}$ & $\begin{array}{c}\text { Neighborhood Number of } \\
\text { The Bank's Branches }\end{array}$ & $\begin{array}{c}\text { Neighborhood Number } \\
\text { of Other Bank Branches }\end{array}$ \\
951 & 142 & 504 \\
\hline
\end{tabular}

The potential banking scores of the counties where the bank's branches are located are as follows:

Table 10: Potential Banking Score Distribution of the Counties in Which the Bank Has Branches

\begin{tabular}{cccc}
\hline Score Range & $\begin{array}{c}\text { Number of The } \\
\text { Bank's Branches }\end{array}$ & $\begin{array}{c}\text { The Number of Counties in } \\
\text { Which the Bank is located }\end{array}$ & $\begin{array}{c}\text { Number of Counties in This } \\
\text { Score Range in Turkey }\end{array}$ \\
\hline $80-100$ & 154 & 26 & 26 \\
$60-80$ & 81 & 32 & 32 \\
$40-60$ & 89 & 62 & 66 \\
$20-40$ & 51 & 50 & 138 \\
$0-20$ & 4 & 4 & 708 \\
Grand Total & $\mathbf{3 7 9}$ & $\mathbf{1 7 4}$ & 970 \\
\hline
\end{tabular}

$62 \%$ of the bank branches ( 235 branches) are located in the two highest score groups. The Bank has its branch in total 58 counties in the two highest score groups in Turkey. In the third high-scoring group, \%94 of the 66 counties have a branch of the Bank. Branches were opened in $36 \%$ of the 138 counties in the fourth group and only $0.6 \%$ in the last 708 counties in the last group.

The branching approach of the bank is quite parallel to the calculation of the potential score of the counties. This situation results in the bank not opening the classical physical branch in the geographical area where the potential score is low and it constitutes $75 \%$ of the counties in Turkey.

Table 11: Potential Banking Score Allocation of the Bank's Branches in Neighborhoods in Istanbul

\begin{tabular}{rccc}
\hline Score Range & $\begin{array}{c}\text { Number of The } \\
\text { Bank's Branches }\end{array}$ & $\begin{array}{c}\text { The Number of } \\
\text { Neighborhoods in Which } \\
\text { the Bank is located }\end{array}$ & $\begin{array}{c}\text { Number of Neighborhood } \\
\text { in This Score Range in } \\
\text { Istanbul }\end{array}$ \\
\hline $80-100$ & 46 & 34 & 40 \\
$60-80$ & 27 & 26 & 52 \\
$40-60$ & 35 & 33 & 121 \\
$20-40$ & 45 & 44 & 363 \\
$0-20$ & 5 & 5 & 375 \\
Total & $\mathbf{1 5 8}$ & $\mathbf{1 4 2}$ & $\mathbf{9 5 1}$ \\
\hline
\end{tabular}

Evaluating 951 neighborhoods in Istanbul, it is seen that 158 branches of the bank are distributed in 142 different neighborhoods. $68 \%$ (108 branches) of the bank's branches are located in the first three high-scoring neighborhood groups. In the last score group, there are only five branches of the Bank in 375 locations.

\section{POTENTIAL LOCATION REVIEW FOR XTM BRANCHES}

When the branches opened by the bank beforehand are examined, it is observed that the average banking potential score of the counties opened up to now is 54. Only 4 of 174 counties, in which a branch opened until today, are between 0-20 score range. All the counties except the one where the bank opened its branches though the score is below 40 points are 
the central counties or the counties of metropolitan cities. By analyzing the interviews with the bank managers and the performance data of the previously opened branches, the following criteria were determined for the Bank's physical and XTM Branch location approach:

$\checkmark \quad$ The counties with banking potential score with a range of 0-20 do not have a sufficient potential to open physical branches. These counties are seen as potential XTM Branch Locations.

$\checkmark$ Since the number of staff in XTM branches is relatively low compared to physical branches, the counties with 10 or more other bank branches are regarded as the locations where the XTM Branch can not compete.

$\checkmark \quad$ XTM Branches can also be positioned at locations with relatively lower potential for banking as they provide cost advantages. The minimum potential banking score is 10 for the opening of XTM Branch and the number of other banks is expected to be minimum 3 .

There are 792 counties where the potential score is below 40 points and the bank has not opened a branch yet. Among these, 45 counties with more than 10 other bank branches are among the potential locations for physical branch opening. Two of the four counties where the bank did not open branches beforehand and has potential banking score around 40-60 provide this criterion and they are considered as the physical branch candidates. There are no counties where the Bank did not open branch among the counties which have a score above 60 points. These results demonstrate that there remains only 47 counties in the country that has enough potential banking score without the Bank has not opened a physical branch yet. If the bank makes use of these locations, the total number of counties in which physical branches have been opened would increase from 174 to 221.

Evaluating the counties that provide the XTM Branch criteria, it was realized that the number of the location with a banking potential score higher than 10 points and a minimum of 3 and a maximum of 9 other bank branches was 219. The Bank can increase its physical penetration by opening XTM branches in another 219 counties. It is observed that the 8 of the new 219 locations are in central counties, 89 of them are in countryside counties and 122 of them are in metropolitan cities. In this way, the Bank will be able to open branches in 8 of the 14 central counties where it is not found suitable to open physical branches and thus, it will be able to increase the physical penetration in the countryside counties where the bank has opened only one branch so far.

\subsection{Additional locations where XTM branch can be opened in Istanbul}

When the Bank's branch locations in Istanbul are examined, the neighborhood distribution of the XTM branches opened by the Bank is as follows:

Table 12: Bank's Score-Based XTM Branch Distribution in Istanbul

\begin{tabular}{rcc}
\hline Score Range & $\begin{array}{c}\text { The Number of The Bank's } \\
\text { XTM Branches }\end{array}$ & $\begin{array}{c}\text { The Number of Neighborhoods } \\
\text { in Which the Bank located its } \\
\text { XTM Branches. }\end{array}$ \\
\hline $80-100$ & 2 & 2 \\
$60-80$ & 2 & 2 \\
$40-60$ & 6 & 5 \\
$20-40$ & 11 & 10 \\
Total & $\mathbf{2 1}$ & $\mathbf{1 9}$ \\
\hline
\end{tabular}

In order to benefit from the cost advantage of the XTM Branch, the Bank is more engaged in the locations which have enough banking potential but not enough for the physical branch cost. Accordingly, while no XTM Branch is opened in the lowest potential score group (0-20), $81 \%$ of the opened branches are located in the second and third lowest score groups. Evaluating the performances of these XTM branches, it was noticed that the two of the five XTM Branches with the highest financial performance are in the neighborhoods of 20-40 score group and the others are in the neighborhoods of other different potential score groups (40-60, 60-80 and 80-100). This indicates that the XTM Branches could also be successful in the neighborhoods of $20-40$ potential score group.

The Bank's strategic approach necessitates that XTM Branches be positioned at locations where there is a potential for banking, but where other banks do not have branch too much. Hence, the 0-20 score group neighborhoods are not regarded as the target location because of not having sufficient potential. Moreover, the neighborhoods with more than 5 other bank branches are also not evaluated as the target location because of having too much competition. In the neighborhoods of 60-80 and 80-100 score groups, the Bank's branch penetration is high. These locations are also considered as the locations where the classical physical branching could sustain. For the XTM Branches- the locations which have at least one, up to 5 other bank branches, and which are in the 20-40 or 40-60 score groups, and the Bank's current 
branch is not available- are selected as the target. It has been figured out that there are 193 locations in this target neighborhood group in Istanbul. Of these, 159 are in the 20-40 potential score group and 34 are in the 40-60 potential score group. Handling these locations, the bank will increase the number of neighborhoods with physical penetration in the 20-40 score group from 44 to 203 and increase the penetration rate to $56 \%$. In the neighborhoods of $40-60$ score group, the number of physically located neighborhoods will increase from 33 to 67 and the penetration rate will increase to $55 \%$.

\section{CONCLUSION}

By evaluating low level of sectoral profitability and the latest technological trends in the last decade, banks have reduced their physical branch investments in their channel strategies and began to more focus on online channels. As marginal transaction costs are rather low compared to physical branches, online platforms are channels in which customers are asked to migrate especially in particular operations.

Nevertheless, it seems that the adaptation to technology in all customer segments is not at the same pace and age, demographic and geographical differences, education and similar features affect this adaptation. In terms of banks, it is not possible to make transactions from end-to-end online channels especially owing to operational and legal obligations in account opening and credit transactions. Such and similar reasons advocate that banks still need a certain amount of physical channels. In Turkey, where physical branch investments are quite high-priced, how to increase the physical market penetration of small and medium-sized banks- whose geographical coverage is far behind large-scale banks- becomes an important question.

XTM Branches are ideal channels for small and medium-sized banks to increase their penetration in micro markets where they have not yet entered and where they are relatively low-potential. As XTM branches do not need operational staff, they are patterns of hybrid channels which can be processed with customer representatives at a much lower cost. It is a channel where the technological approach is combined with the physical contact and the customer's technological adaptations can be directed in a positive direction by a correct business modeling.

In this study, current physical market penetration and spreading strategy of a bank was investigated through the usage of this medium-sized bank's data. The conclusions demonstrate that the Bank can increase its physical market coverage level more than double in Turkey by using the cost advantage of its XTM Branches.

\section{REFERENCES}

Akın, F., Karaboğa, K. 2011, “Bireysel Müşterilerin Şubesiz Bankacılık Hizmetlerini Kullanma Kararına Etki Eden Faktörlerin Belirlenmesi Üzerine Bir Araştırma: Bilecik Örneği”, Marmara Üniversitesi i.i..B.F. Dergisi, no. 1, pp. 301-320.

Angelakopoulos, G., Mihiotis, A. 2011, "E-banking: challenges and opportunities in the Greek banking sector", Electron Commer Res, vol. 11, pp. 297-319. (Springer Science+Business Media, LLC 2011, published online: 3 March 2011).

Baker, E. W., Gahtani, S. S., Hubona, G. S. 2007, "The Effects of Gender and Age on New Technology Implementation in a Developing Country: Testing the Theory of Planned Behavior (TPB)", Information Technology \& People, Vol. 20, No. 4, pp. 352-375.

Banking Regulation and Supervision Agency, December 2016, "Turkish Banking Sector Interactive Monthly Bulletin".

Başar, A., Kabak, Ö., Topçu, İ. 2015, “Banka Şubeleri İçin Uygun Yer Seçiminin Belirlenmesine Yönelik Tabu Arama Yaklaşımı: Bir Türk Bankası Uygulaması”, Endüstri Mühendisliği Dergisi, Vol: 26, No: 3, pp. 2-22.

Cebeci, İ. 2015, “İnternet Bankacılığına Yönelik Öğrenci Tutumlarının İncelenmesi”, The Journal of International Social Research, Vol. 8, No. 39, pp. 793-803.

Cebi, F., Zeren, Z. 2008, “A Decision Support Model for Location Selection: Bank Branch Case”, PICMET 2008 Proceedings, $27-31$ July, Cape Town, South Africa, pp. 1069-1074.

Chavan, J. 2013, "Internet Banking - Benefits and Challenges in an Emerging Economy", International Journal of Research in Business Management (IJRBM), Vol. 1, Issue 1, pp. 19-26.

Cinar, N. 2009, "A Decision Support Model for Bank Branch Location Selection”, World Academy of Science, Engineering and Technology International Journal of Mathematical, Computational, Physical, Electrical and Computer Engineering Vol:3, No:12, pp. 1092-1097. 
Çınar, N. T. 2011, "Fuzzy Topsis Methods in Group Decision Making and an Application for Bank Branch Location Selection", Journal of Engineering and Natural Sciences, Vol. 29, pp. 11-24.

Durer, S., Çalışkan, A. Ö., Akbaş, H. E., Gündoğdu, C. E. 2009, “İnternet Bankacılığını Kullanma Kararını Etkileyen Faktörler: Türk Banka Müşterileri Üzerine Bir Araştırma", Marmara Üniversitesi i.i.i.B.F. Dergisi, Vol. 26, No. 1, pp. 133-154.

Gerrard, P., Cunningham, J. B., Devlin, J. F. 2006, "Why Consumers Are Not Using Internet Banking: A Qualitative Study", Journal of Services Marketing, Vol. 20, No. 3, pp. 160-168.

Kaya, F., Arslan, T. R. 2016, "Internet Bankacılığında Müşterilerin Banka Tercihlerine Etki Eden Faktörler: Bolu illinde Kamu Çalışanları Üzerine Bir Araştırma”, Finansal Araştırmalar ve Çalışmalar Dergisi, Vol. 8, No. 15, pp. 423-449.

Khalilov, M. C. K., Gündebahar, M. 2012, "XTM: An Alternative Delivery Channel in Turkish Banking Sector", Procedia - Social and Behavioral Sciences, vol. 57, pp. $373-380$.

Koskosas, I. 2011, "The Pros and Cons of Internet Banking: A Short Review", Business Excellence and Management, Vol. 1, Issue 1, pp. 4958.

Lee, J., Jaramillo, M. 2013, "Driving Adoption of Branchless Banking: insights from consumer education in India, the Philippines, and Zambia", Enterprise Development and Microfinance, Vol. 24, No. 3, pp. 218-232.

Mermod, A. Y. "Customer's Perspectives and Risk Issues on E-Banking in Turkey; Should We Still be Online?", http://www.icommercecentral.com/open-access/customers-perspectives-and-risk-issues-on-ebanking-in-turkey-should-we-still-be online.php?aid=38152, 05/03/2017.

Meuter, M. L., Bitner, M. J., Ostrom A. L., Brown, S. W. 2005, "Choosing Among Alternative Service Delivery Modes: An Investigation of Customer Trial of Self-Service Technologies", Journal of Marketing, Vol. 69, pp. 61-83.

Oktay, E., Orçanlı, K. 2014, "Atatürk Üniversitesinde İnternet Bankacılığının Kullanımını Etkileyen Faktörlerin Belirlenmesi”, Uşak Üniversitesi Sosyal Bilimler Dergisi, Vol. 7, No. 2, pp. 57-91.

Okumus, A., Bozbay, Z., Dağlı, R. M. 2010, "Banka Müşterilerinin İnternet Bankacılığına İlişkin Tutumlarının İncelenmesi”, Erciyes Üniversitesi İktisadi ve İdari Bilimler Fakültesi Dergisi, Vol: 36, pp. 89-111.

Ozdemir, S., Trott, P., Hoecht, A. 2008, "'Segmenting internet banking adopter and non-adopters in the Turkish retail banking sector", International Journal of Bank Marketing, Vol. 26, No. 4, pp. 212-236.

Pala, E., Kartal, B. 2010, “Banka Müşterilerinin İnternet Bankacılığı ile İlgili Tutumlarına Yönelik Bir Pilot Araştırma”, Yönetim ve Ekonomi, Vol.:17, No. 2, pp. 43-61.

Rotchanakitumnuai, S., Speece, M. 2003, "Barriers to Internet Banking Adoption: A Qualitative Study Among Corporate Customers in Thailand", International Journal of Bank Marketing, Vol. 21, No. 6, pp. $312-323$.

Soba, M. 2014, "Banka Yeri Seçiminin Analitik Hiyerarşi Süreci ve Electre Metodu ile Belirlenmesi: Uşak İlçeleri Örneği”, Mustafa Kemal University Journal of Graduate School of Social Sciences, Vol:11, Issue: 25, pp. 459-473.

Thakur, R., Srivastava, M. 2014, "Adoption Readiness, Personal Innovativeness, Perceived Risk and Usage Intention Across Customer Groups for Mobile Payment Services in India", Internet Research, Vol. 24, No. 3, pp. 369-392.

Turkish Bankers Association, June 2016, “Bank Ranking by Asset Size”.

Turkish Bankers Association, December 2011, "Internet and Mobile Banking Statistics".

Turkish Bankers Association, December 2016, "Internet and Mobile Banking Statistics".

Usta, R. 2005, "Tüketicilerin İnternet Bankacılığını Kullanma Nedenleri Üzerine Bir Araştırma”, Dogus Üniversitesi Dergisi, vol. 6, no. 2, pp. 279-290.

Ustasüleyman, T., Eyüboğlu, K. 2010, “Bireylerin İnternet Bankacılığını Benimsemesini Etkileyen Faktörlerin Yapısal Eşitlik Modeli ile Belirlenmesi", BDDK Bankacılık ve Finansal Piyasalar, Vol. 4, No. 2, pp. 11-38.

Venkatesh, V., Davis, F. 2000, "A Theoretical Extension of the Technology Acceptance Model: Four Longitudinal Field Studies", Management Science (C) 2000 INFORMS, Vol. 46, No. 2, pp. 186-204.

Weon, H. J., Eui, H. W., Sik, K. Y. 2010, "The Study of Location Strategy for Bank through the Analysis of Inter-regional Financial Transaction Network", International Journal of u- and e- Service, Science and Technology, Vol. 3, No. 1, pp. 21-30.

Willer, D. 1990, “A Spatial Decision Support System For Bank Location: A Case Study”, National Center for Geographic Information and Analysis Department of Geography State University of New York at Buffalo, Technical Report 90-9.

Yap, K., Wong, H. W., Loh, C., Bak, R. 2009, “Offline and online banking -where to draw the line when building trust in e-banking?, International Journal of Bank Marketing Vol. 28 No. 1, 2010 pp. 27-46. 
Yıldız, S., Karadirek, G. 2014, "Elektronik Hizmet Kalitesi Algılamaları: Bireysel İnternet Bankacılığı Kullanıcıları Üzerine Bir Uygulama”, Gümüşhane Üniversitesi Sosyal Bilimler Elektronik Dergisi, No. 10, pp. 303-329.

Yuen, Y. Y., Yeow, P. H. P., Lim, N. 2015, "Internet Banking Acceptance in the United States and Malaysia: A Cross-cultural Examination", Marketing Intelligence \& Planning, Vol. 33, No. 3, pp. 292-308. 